\title{
Ljungan Virus and an Adenovirus in Italian Squirrel Populations
}

\begin{abstract}
Claudia Romeo, ${ }^{1,6}$ Nicola Ferrari, ${ }^{2}$ Chiara Rossi, ${ }^{3}$ David J. Everest, ${ }^{4}$ Sylvia S. Grierson, ${ }^{4}$ Paolo Lanfranchi, ${ }^{2}$ Adriano Martinoli, ${ }^{5}$ Nicola Saino, ${ }^{1}$ Lucas A. Wauters, ${ }^{5}$ and Heidi C. Hauffe ${ }^{3}{ }^{1}$ Department of Biosciences, Università degli Studi di Milano, v. Celoria 26, 20133, Milan, Italy; ${ }^{2}$ Department of Veterinary Sciences and Public Health, Università degli Studi di Milano, Via Celoria 10, 20133, Milan, Italy; ${ }^{3}$ Department of Biodiversity and Molecular Ecology, Fondazione Edmund Mach, Via E. Mach 1, 38010, S. Michele all'Adige, Italy; ${ }^{4}$ Department of Virology, Animal Health and Veterinary Laboratories Agency-Weybridge, New Haw, Addlestone, Surrey KT15 3NB, UK; ${ }^{5}$ Department of Theoretical and Applied Sciences, Università degli Studi dell'Insubria, Via J.H. Dunant, 3, 21100, Varese, Italy; ${ }^{6}$ Corresponding author (email: claudia.romeo@ unimi.it)
\end{abstract}

ABSTRACT: We report Ljungan virus infection in Eurasian red squirrels (Sciurus vulgaris) for the first time, and extend the known distribution of adenoviruses in both native red squirrels and alien gray squirrels (Sciurus carolinensis) to southern Europe.

The introduction of alien species is one of the major causes of infectious disease emergence in wildlife, representing a threat not only to biodiversity conservation, but also to domesticated animals and humans (Daszak et al. 2000). Alien species can introduce new pathogens, alter the epidemiology of local pathogens, become reservoir hosts, and increase disease risk for native species (Prenter et al. 2004; Dunn 2009).

As part of a broader project to study the role of infectious diseases and parasites in the competition between alien and native species, we investigated Ljungan virus (LV) and adenovirus infections in introduced North American eastern gray squirrels (Sciurus carolinensis) and native Eurasian red squirrels (Sciurus vulgaris) in northern Italy. More specifically, we investigated whether arboreal sciurids are involved in $\mathrm{LV}$ circulation, and if adenovirus infection in squirrels is present in Italy.

Ljungan virus was isolated in 1999 (Niklasson et al. 1999), and has subsequently been detected in many species of small rodents, especially voles (Arvicolinae; Johansson et al. 2003; Hauffe et al. 2010; Salisbury et al. 2013). In northern Italy, this virus has been reported in a small sample of bank voles (Myodes glareolus) and yellow-necked mice (Apodemus flavicollis) with $50 \%$ and $10 \%$ prevalence, respectively (Hauffe et al. 2010). Although its zoonotic potential is still debated, $\mathrm{LV}$ has been associated with type 1 diabetes (T1D), myocarditis, and several gestational diseases in humans (McDonald 2009; Blixt et al. 2013). Experimentally infected laboratory mice develop signs of these same diseases, and LV-infected wild voles can also develop T1D-like syndromes (McDonald 2009; Blixt et al. 2013).

Outbreaks of enteric adenovirus infections associated with gastrointestinal disease and mortality have been described in both free-living and captive red squirrels in Germany and the UK (e.g., MartínezJiménez et al. 2011; Peters et al. 2011), where subclinical adenovirus infections among introduced gray squirrels have also been reported (Everest et al. 2009).

We analyzed 232 gray squirrels from five populations, culled as part of a control program (2011-12), and 77 road-killed red squirrels for adenoviruses. All the specimens were collected in Piedmont and Lombardy regions (between $44^{\circ} 35^{\prime} 55^{\prime \prime}$ and $46^{\circ} 35^{\prime} 55^{\prime \prime} \mathrm{N} ; 7^{\circ} 37^{\prime} 41^{\prime \prime}$ and $\left.10^{\circ} 32^{\prime} 08^{\prime \prime} \mathrm{W}\right)$. For adenovirus analysis, sample sets of both squirrel species were heterogeneous for sex, age class, and season of collection. For LV analysis, we used a subset of adult squirrels collected in autumn (49 gray squirrels and nine red squirrels), to maximize the chance of finding the virus, because infection is assumed to be correlated with small mammal (host) density and, therefore, probability of exposure ( $\mathrm{HCH}$ and others, unpubl.).

For LV screening, total RNA was extracted from liver (stored at $-80 \mathrm{C}$ ) using the RNeasy Lipid Tissue Mini Kit (Qiagen, Hilden, Germany). We performed 
a One-Step reverse transcriptase-PCR (Qiagen) in duplicate, using primers described by Donoso Mantke et al. (2007). Amplicons were purified using the PureLink Quick gel Extraction and PCR Purification Combo Kit (Invitrogen, Carlsbad, California, USA) and directly sequenced using the Big Dye terminator cycle sequencing kit (Applied Biosystems, Foster City, California, USA) on an ABI 3130 sequencer. Sequences (189 base pairs) were checked using the basic local alignment search tool (NCBI 2013). For adenovirus screening, nucleic acid was extracted from spleen tissue (stored at $-20 \mathrm{C}$ ), using the manufacturer's recommendations for the QIAamp DNA Mini kit (Qiagen). We performed nested PCR using primers described by Everest et al. (2012). To confirm the specificity of the primers, amplicons were recovered from agarose gels and purified using the Qiaquick Gel extraction kit (Qiagen), and then used as templates in direct dye-termination sequence reactions (Big Dye Terminator Cycle Sequencing Ready Reaction; Applied Biosystems).

Two red squirrels (22\%), but no gray squirrels, were infected with LV. An adenovirus was detected in $12(16 \%)$ red squirrels and two $(0.9 \%)$ gray squirrels. No cases of coinfection were detected.

To our knowledge this is the first record of $\mathrm{LV}$ in the Eurasian red squirrel, indicating that the infection is not limited to small, ground-dwelling rodents, and extending the potential host-spectrum of $\mathrm{LV}$ to arboreal mammals. Little is known about the circulation of $\mathrm{LV}$ in the environment; however, one of our sequences was identical to a widespread haplotype found in several rodent species across Europe, and the other was identical to a haplotype carried by bank voles in Lombardy (Hauffe et al. 2010), suggesting that squirrels might play an active part in both intra- and interspecific LV circulation; further ecologic and phylogenetic analyses are underway to confirm this.

Poor preservation of road kills did not allow us to identify clinical signs of infection in adenovirus-positive red squirrels, whereas infected, freshly killed, gray squirrels did not show any abnormalities at postmortem examination. All the adenovirus-infected red squirrels were collected in areas where the alien species is not present. Moreover, the two positive gray squirrels lived in areas where the native species is still present or was present until recently. Our findings extend adenovirus distribution in red and gray squirrels to southern Europe, but the gray squirrel does not appear, from these results, to be the source of adenovirus infection in the native species. Our results are consistent with recent findings by Everest et al. (2013) suggesting that the infection could be maintained by the native species or by other sympatric woodland rodents such as wood mice (Apodemus sylvaticus).

Despite the limitations of this study (in particular, potential biases linked to convenience sampling and small sample sizes), we show for the first time that red squirrels can be infected with $\mathrm{LV}$, and that one or more adenoviruses are present in southern Europe. We cannot determine whether squirrels are reservoir hosts of these infections, or whether these are results of spillover from other small mammal species (e.g., voles) in the same ecosystem. Transmission of infectious diseases in arboreal sciurids is still poorly understood; their role in disease emergence could be underestimated and further research to disclose their epidemiologic significance is needed.

We thank European Squirrel Initiative and the Fondazione Edmund Mach for funding. The project was supported by the Italian Ministry of Education, University and Research (PRIN 2010-2011, 20108 TZKHC to Università degli Studi dell'Insubria, Varese). This work was also partially financed by the European Union grant FP7-261504 EDENext and is catalogued by the EDENext Steering Committee as EDENext 187 (http://www.edenext. eu). Thanks also to the Animal Health and Veterinary Laboratories Diseases of 
Wildlife Scheme for assistance with the adenovirus analyses. Finally, sample collection would not have been possible without the help of the LIFE09 NAT/ IT/00095 EC-SQUARE.

\section{LITERATURE CITED}

Blixt M, Sandler S, Niklasson B. 2013. Ljungan Virus and Diabetes. In: Diabetes and viruses, Taylor $\mathrm{K}$, Hyöty H, Toniolo A, Zuckerman AJ, editors. Springer, New York, New York, pp. 81-86.

Daszak P, Cunningham AA, Hyatt AD. 2000. Emerging infectious diseases of wildlife-Threats to biodiversity and human health. Science 287:443-449.

Donoso Mantke O, Kallies R, Niklasson B, Nitsche A, Niedrig M. 2007. A new quantitative real-time reverse transcriptase PCR assay and melting curve analysis for detection and genotyping of Ljungan virus strains. J Virol Methods 141:71-77.

Dunn AM. 2009. Parasites and biological invasions. Adv Parasitol 68:161-184.

Everest DJ, Grierson SS, Stidworthy MF, Shuttleworth C. 2009. PCR detection of adenovirus in grey squirrels on Anglesey. Vet Rec 165:482.

Everest DJ, Shuttleworth CM, Grierson SS, Duff JP, Jackson N, Litherland P, Kenward RE, Stidworthy MF. 2012. Systematic assessment of the impact of adenovirus infection on a captive reintroduction project for red squirrels (Sciurus vulgaris). Vet Rec 171:176.

Everest DJ, Butler H, Blackett T, Simpson VR, Shuttleworth CM. 2013. Adenovirus infection in red squirrels in areas free from grey squirrels. Vet Rec 173:199-200.

Hauffe HC, Niklasson B, Olsson T, Bianchi A, Rizzoli A, Klitz W. 2010. Ljungan virus detected in bank voles (Myodes glareolus) and yellow-necked mice (Apodemus flavicollis) from northern Italy. J Wildl Dis 46:262-266.

Johansson ES, Niklasson B, Tesh RB, Shafren DR, da Rosa APAT, Lindberg AM. 2003. Molecular characterization of M1146, an American isolate of Ljungan virus $(\mathrm{LV})$ reveals the presence of a new LV genotype. J Gen Virol 84:837-844.

Martínez-Jiménez D, Graham D, Couper D, Benkö M, Schöniger S, Gurnell J, Sainsbury AW. 2011. Epizootiology and pathologic findings associated with a newly described adenovirus in the red squirrel, Sciurus vulgaris. J Wildl Dis 47:442454.

McDonald AG. 2009. Ljungan virus: An emerging zoonosis? Clin Microbiol Newsl 31:177-182.

[NCBI] National Center for Biotechnology Information. Basic Local Alignment Search Tool, http:// blast.ncbi.nlm.nih.gov/Blast.cgi. Accessed December 2013.

Niklasson B, Kinnunen L, Hörnfeldt B, Hörling J, Benemar C, Olof Hedlund K, Matskova L, Hyypiä T, Winberg G. 1999. A new Picornavirus isolated from bank voles (Clethrionomys glareolus). Virology 255:86-93.

Peters M, Vidovszky MZ, Harrach B, Fischer S, Wohlsein P, Kilwinski J. 2011. Squirrel adenovirus type 1 in red squirrels (Sciurus vulgaris) in Germany. Vet Rec 169:182b.

Prenter J, MacNeil C, Dick JT, Dunn AM. 2004. Roles of parasites in animal invasions. Trends Ecol Evol 19:385-390.

Salisbury A-M, Begon M, Dove W, Niklasson B, Stewart JP. 2013. Ljungan virus is endemic in rodents in the UK. Arch Virol. DOI: 10.1007/ s00705-013-1731-6.

Submitted for publication 7 October 2013.

Accepted 19 October 2013. 